\title{
QUALITATIVE ANALYSES OF GAS EVOLUTION FROM MODIFIED CELLULOSE MIXTURES DURING THERMAL DEGRADATION IN AIR AND ARGON
}

\author{
Zbigniew Zawieja ${ }^{1}$, Jacek Sawicki ${ }^{1}$ \\ 1 Lodz University of Technology, Institute of Materials Science and Engineering, Stefanowskiego St. 1/15, \\ 90-924 Lodz, Poland, e-mail:800521@edu.p.lodz.pl
}

Received: 2017.05.15

Accepted: 2017.08.01

Published: 2017.09.03

\begin{abstract}
This paper presents the application of mineral additives, such as expanded perlite, expanded vermiculite and microspheres in items used in founding. Mixed with paper pulp and aluminosilicate resin as a binder, these additives are the base of a mixture patented by the authors, which can be used in the production of pipe shapes and connectors with a circular cross-section in casting systems in the founding industry. These mixtures were subjected to TG thermal degradation during which a quantitative analysis of the emitted fumes was carried out. The analysis did not detect any other compounds than those formed by the combustion of cellulose materials, which indicated that no chemical reaction took place between the applied additives and cellulose at high temperatures.
\end{abstract}

Keywords: expanded perlite, expanded vermiculite, microspheres, cellulose mixture, mass spectrometry.

\section{INTRODUCTION}

Cellulose is a material that has been wellknown for many years; owing to its properties, it is widely used in many industrial and scientific applications. Pure or modified, cellulose is increasingly becoming the subject of numerous scientific studies. These studies endeavor to elucidate the mechanisms and processes which take place in cellulose-based materials when external conditions, such as temperature, change $[12,13$, $14,17,21,22,23,25,26]$. A high-temperature thermal treatment of cellulose-based materials naturally results in thermal degradation associated with mass loss which turns into gaseous by-products. The analysis of the kinetics of these changes allows us to develop a composition of cellulose mixtures depending on the temperature range in which they are to be used, while at the same time, reducing - if possible - the amount of gaseous by-products emitted. This is closely linked to global trends to reduce the emission of harmful substances which may form during the thermal degradation of materials. This paper analyses the thermal degradation of a novel mixture patented by the authors [24]. This cellulosebased mixture was modified with natural additives, such as expanded vermiculite $[4,5,8,15$, $16]$, expanded perlite $[1,10,18,20]$ and microspheres $[2,6,7]$; inorganic resins were used as a binder [3,9]. Expanded perlite and vermiculite have very interesting physicochemical properties, such as: large absorption capacity for liquids, low bulk density, high thermal resistance of a neutral chemical nature and negligible chemical reactivity. The addition of microspheres whose thermal insulating power is similar to that of previous additives, enhances the thermal insulating power of the mixture to certain temperature levels, when the microspheres decompose, which generates a strong exothermic effect $[2,25,26]$. The samples under analysis contained an organic geopolymer 
binder, whose interesting properties have made the authors use the material as an alternative to other organic binders used in hazardous cellulose-based mixtures [11].

\section{MATERIALS AND METHODOLOGY}

Four samples were analyzed; their composition is presented in Table 1. Additional analyses were carried out for the mineral additives used to produce the samples. Sorted Ekofiber waste paper was used to produce paper pulp; it was treated

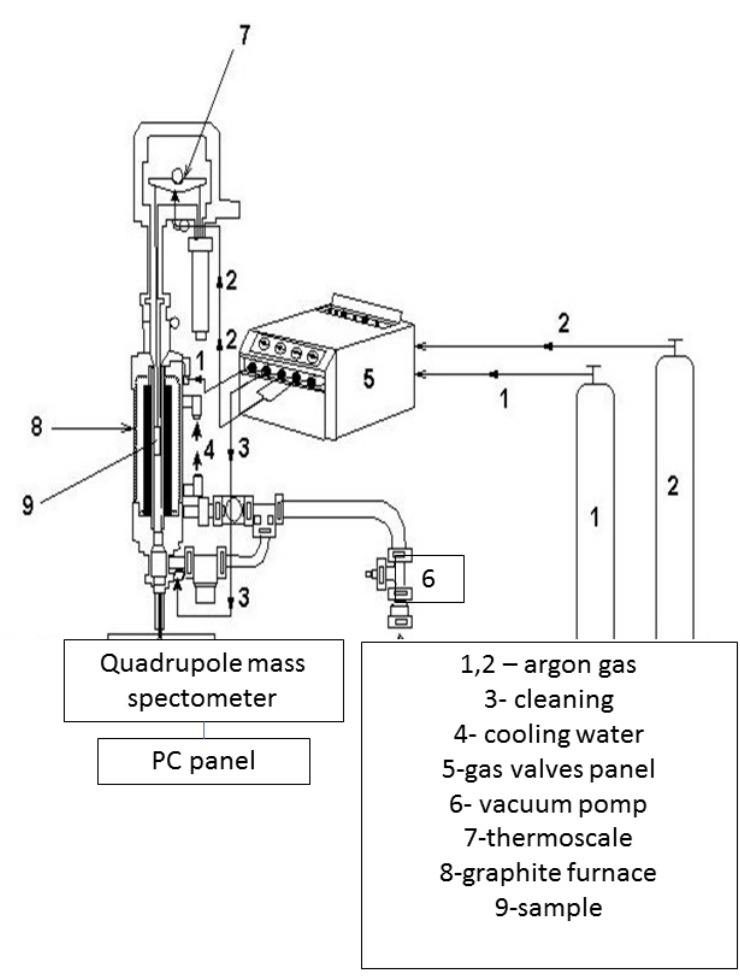

Fig. 1. Measurement scheme with quadrupole mass spectrometer with water at a temperature of $60^{\circ} \mathrm{C}$ and mixed with the other ingredients according to the proportions given in Table 1. All the ingredients were mixed and subsequently the samples were dried at a temperature of $130^{\circ} \mathrm{C}$ for 75 minutes.

The samples were subjected to thermal decomposition in a "Setsys TG- DTG 16" device manufactured by Setaram (France). The measurements were taken under the dynamic conditions of air and argon stream. A diagram of the measurement stand is shown in Fig. 1.

The air and argon flow rate during the measurement was $40 \mathrm{~cm}^{3} / \mathrm{min}$. The sample (9) was placed in platinum crucibles coupled with a thermobalance beam (7). A sample usually weighing under $10 \mathrm{mg}$ was placed in a crucible in a graphite furnace (8) heated up at a linear rate of $10^{\circ} \mathrm{C}$ per minute. Measurements were made starting at an ambient temperature up to a maximum temperature of $1000^{\circ} \mathrm{C}$. The graphite interior of the furnace was protected against oxidizing with argon as a protective gas (2) which washed the furnace during its operation. The furnace is cylindrical and it is cooled down by water circulation. It is controlled and regulated by means of a flow regulation panel (5). Carrier gas is supplied under normal pressure during the thermoanalytical measurements. The purpose of washing with gas is to remove fumes emitted by the sample from the furnace chamber. The washing gas (argon) can protect a sample from its oxidation while it is heated. Qualitative analysis on a quadrupole mass spectrometer "ThermoStar" manufactured by Balzers (Germany) was carried out simultaneously with the thermal degradation process. The spectrometer was calibrated to measure molecules at molecular weights ranging from 2 to 78 [g/mol].

Table 1. The material composition of the patented shapes used for the investigations

\begin{tabular}{|c|c|c|c|c|c|}
\hline & $\begin{array}{c}\text { Paper pulp } \\
\text { [g] }\end{array}$ & $\begin{array}{c}\text { Exp. Perlite } \\
\text { [g] }\end{array}$ & $\begin{array}{c}\text { Exp. Vermiculite } \\
\text { [g] }\end{array}$ & $\begin{array}{c}\text { Inorganic binder } \\
\text { [g] }\end{array}$ & $\begin{array}{c}\text { Microspheres } \\
\text { [g] }\end{array}$ \\
\hline $\begin{array}{c}\text { Sample with no } \\
\text { additives }\end{array}$ & $\begin{array}{c}250 \text { (25 g Ekofiber } \\
+225 \mathrm{~g} \text { water })\end{array}$ & 0 & 0 & 140 & 0 \\
\hline $\begin{array}{c}\text { Sample with ex- } \\
\text { panded perlite }\end{array}$ & $\begin{array}{c}250(25 \mathrm{~g} \text { Ekofiber } \\
+225 \mathrm{~g} \text { water })\end{array}$ & 25 & 0 & 140 & 140 \\
\hline $\begin{array}{c}\text { Sample with } \\
\text { expanded } \\
\text { vermiculite }\end{array}$ & $\begin{array}{c}250(25 \mathrm{~g} \text { Ekofiber } \\
+225 \mathrm{~g} \text { water })\end{array}$ & 0 & 25 & 140 & 75 \\
\hline $\begin{array}{c}\text { Sample with ex- } \\
\text { panded perlite, } \\
\text { vermiculite and } \\
\text { microspheres }\end{array}$ & $\begin{array}{c}250(25 \mathrm{~g} \text { Ekofiber } \\
+225 \mathrm{~g} \text { water })\end{array}$ & 25 & 25 & & \\
\hline
\end{tabular}




\section{RESULTS}

The analysis of all the test results from the mass spectrometer omitted results of $\mathrm{H}_{2}, \mathrm{H}_{2} \mathrm{O}$,
$\mathrm{O}_{2}, \mathrm{~N}_{2}$ and Ar. The other spectra at a level of $10^{-13}$ or lower which were classified as the measurement of noise contaminations were also omitted. After the results were filtered according to

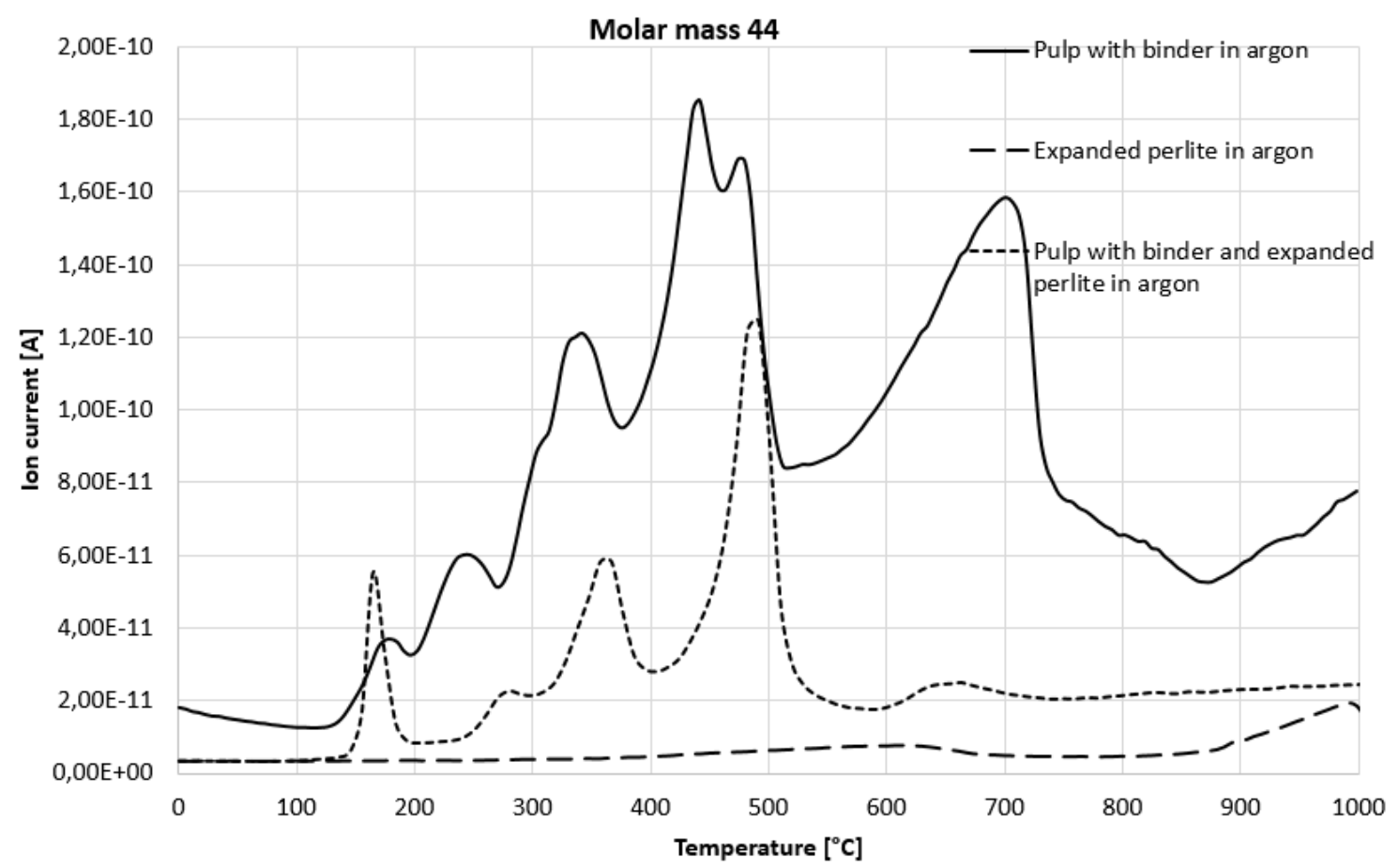

Fig. 2. Expanded perlite influence on mixture degradation observed at a molar mass of 44 - evolution in argon

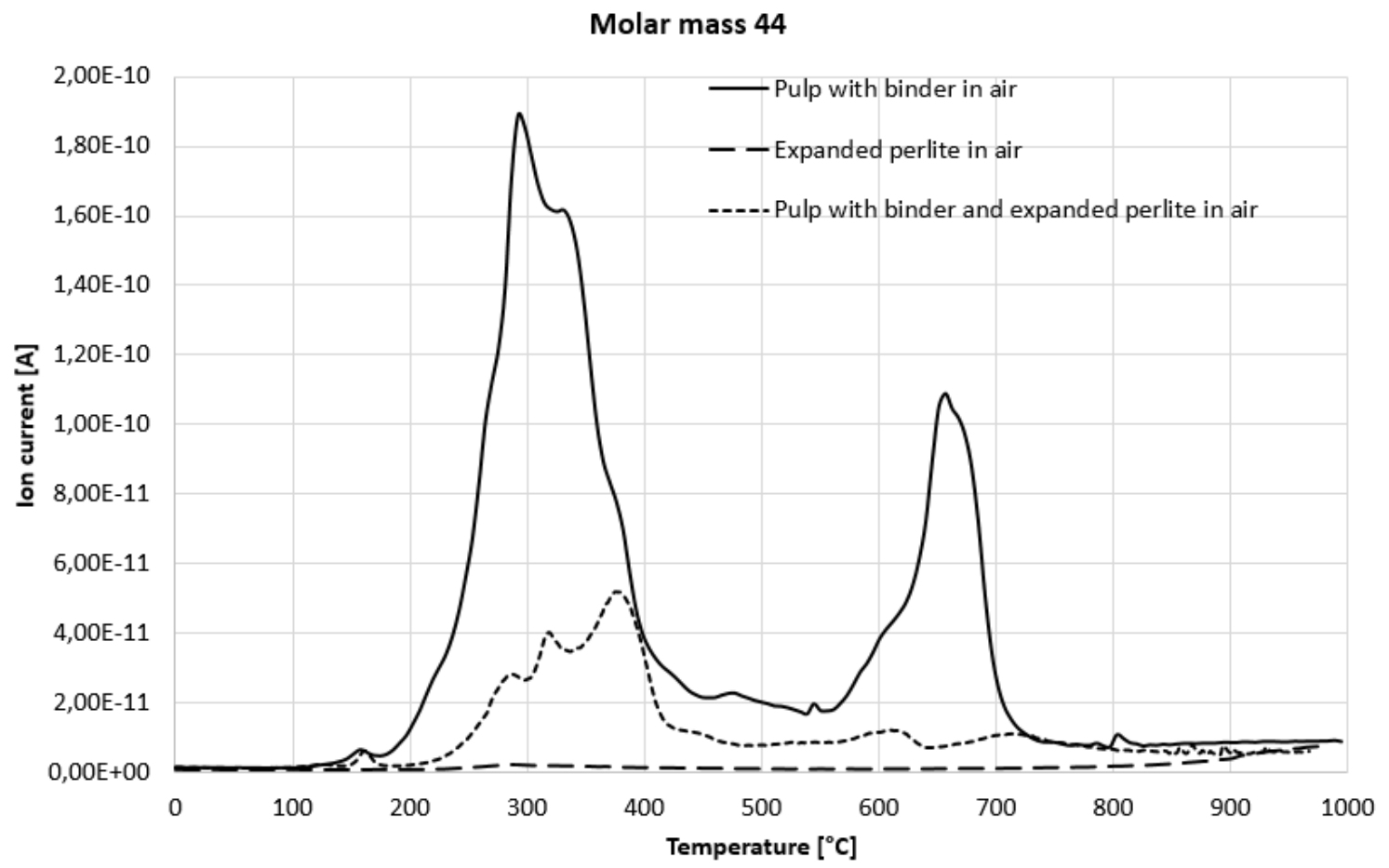

Fig. 3. Expanded perlite influence on mixture degradation observed at a molar mass of 44 - evolution in air 


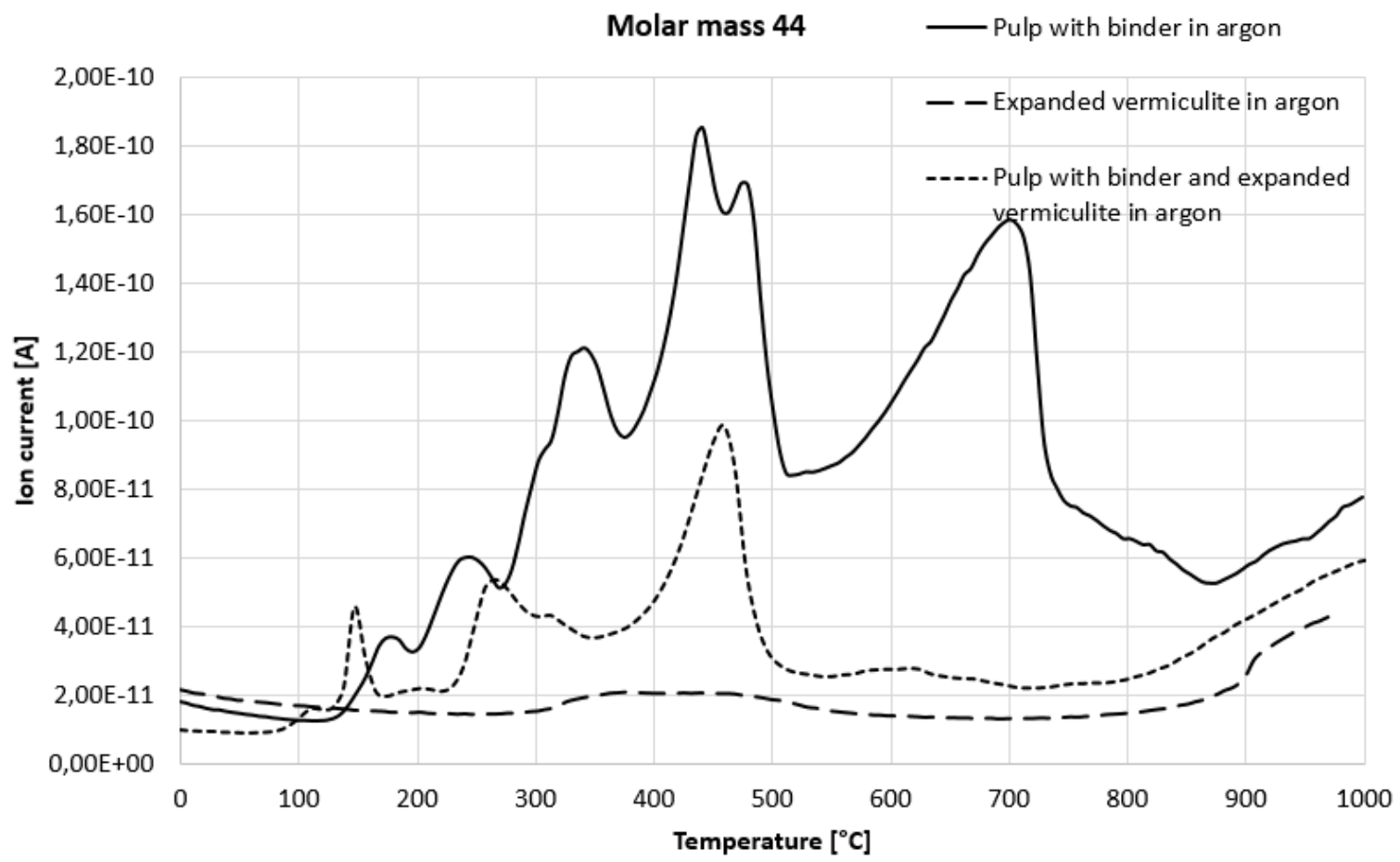

Fig. 4. Expanded vermiculite influence on mixture degradation observed at a molar mass of 44 - evolution in argon

this principle, the molecular weight of 44 from the emitted sample remained for analysis. The molecular weight of 44 may be attributed to the emission of the following compounds: $\mathrm{C}_{3} \mathrm{H}_{8}, \mathrm{CO}_{2}$ , $\mathrm{C}_{2} \mathrm{H}_{5} \mathrm{OH}$. Since a cellulose mixture is the main component of the samples and the research process was related to thermal degradation, it should be assumed that carbon dioxide is the main gas emitted from the samples.

The results for a sample with an addition of expanded perlite analyzed in argon are shown in Fig. 2 and in air - in Fig. 3. For a comparative analysis, the results for the paper pulp only with the aluminosilicate binder and pure expanded perlite, in argon and in air, respectively, were plotted on the graph.

The decomposition of cellulose in the mixture under study takes place regardless of the type of atmosphere, what was demonstrated in other studies $[12,13,14,17]$. The first effect, associated with the decarbonization of cellulose, takes place in a temperature range between $189^{\circ} \mathrm{C}$ do $381^{\circ} \mathrm{C}$. The next range is between $577^{\circ} \mathrm{C}$ and $702^{\circ} \mathrm{C}$, which is attributed to cellulose degradation. The admixture of expanded perlite considerably reduces carbon dioxide emission in the thermal degradation process of the mixture under study. This is caused by the fact that pure expanded per- lite does not emit considerable amounts of $\mathrm{CO}_{2}$ throughout the temperature range of the experiment. It is clearly visible in Fig. 2 that pure perlite examined in argon is more prone to emit carbon dioxide than in air, which may indicate that gas can be absorbed by expanded perlite. The hygroscopic properties of expanded perlite $[18,20]$ can also indicate that it is capable of absorbing gases.

Fig. 4 and Fig. 5 show the effect of expanded vermiculite on carbon dioxide emission from a mixture with the addition of expanded vermiculite and waste paper pulp with an aluminosilicate binder in argon and in air.

The analysis of the results of the gas emission during the thermal degradation process of the sample with expanded vermiculite shows that the thermal degradation of the samples is usually similar to that of a sample with expanded perlite, regardless of the atmosphere. There is also a visible effect of absorbing carbon dioxide during the second stage of releasing $\mathrm{CO}_{2}$ by expanded vermiculite in a temperature range of $550-730^{\circ} \mathrm{C}$ from a sample with an admixture of vermiculite compared to a sample with no mineral additives. During a later stage, above a temperature of $881^{\circ} \mathrm{C}$, secondary decarbonization occurs, which is a consequence of the natural properties of these types of materials [26]. 


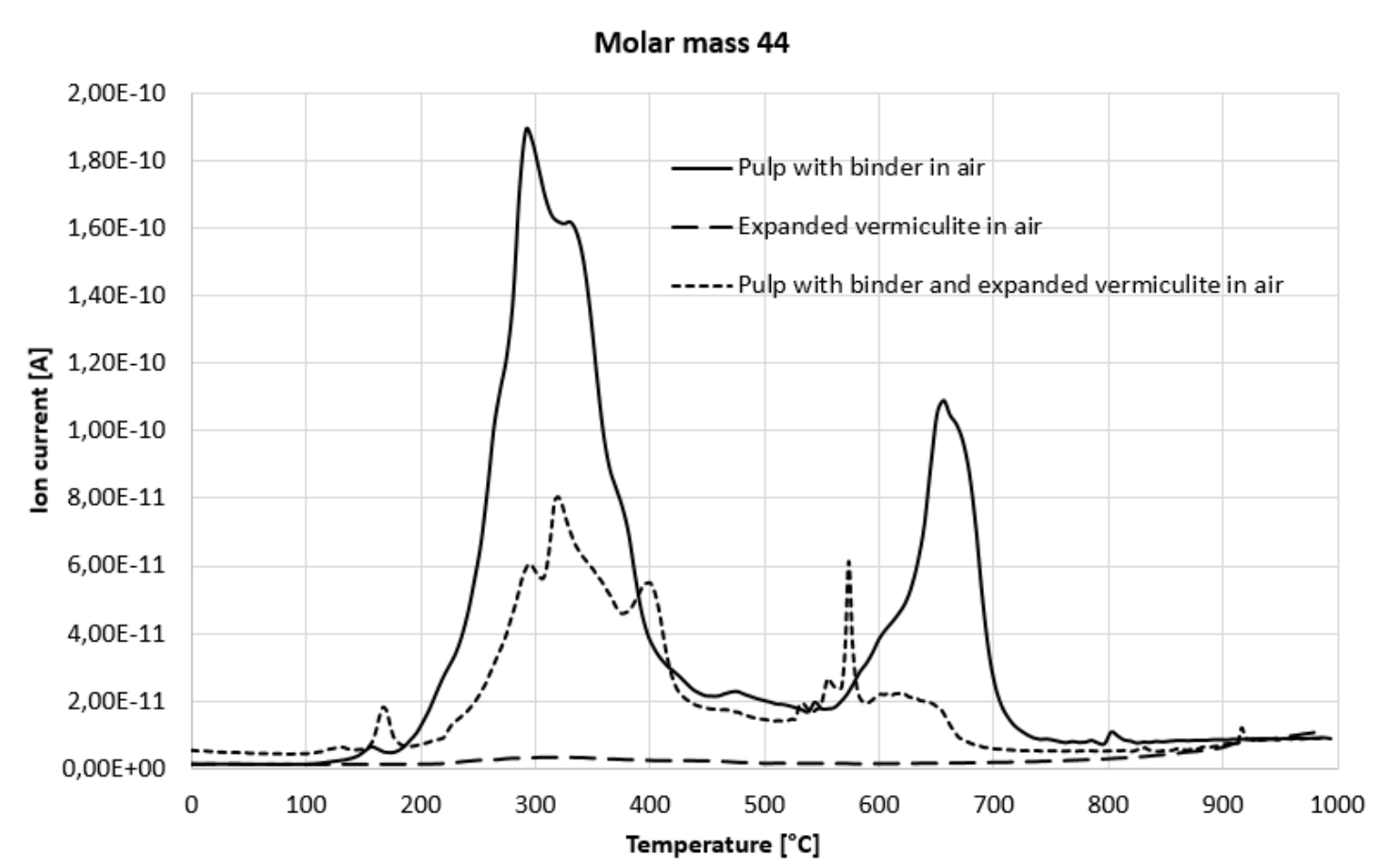

Fig. 5. Expanded vermiculite influence on mixture degradation observed at a molar mass of 44 - evolution in air

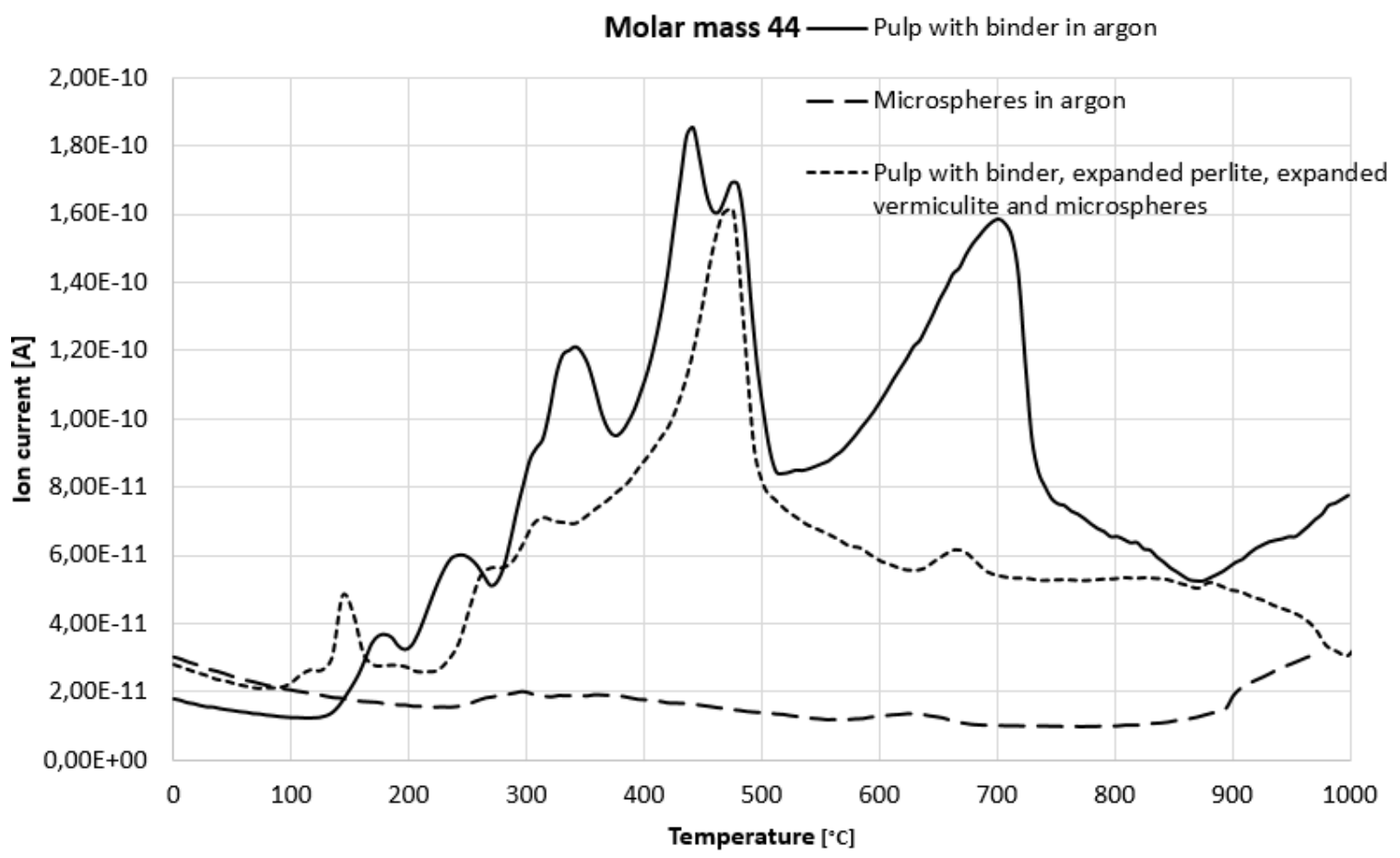

Fig. 6. Expanded perlite, expanded vermiculite and microspheres influence on mixture degradation observed at a molar mass of 44 - evolution in argon

The results of tests with an admixture of expanded perlite sample, expanded vermiculite and microspheres in argon and air are shown in Fig. 6 and Fig. 7.
Thermal degradation during a test with an admixture of expanded perlite sample, expanded vermiculite and microspheres in argon (Fig. 6) is similar to that of previous samples, which is at- 


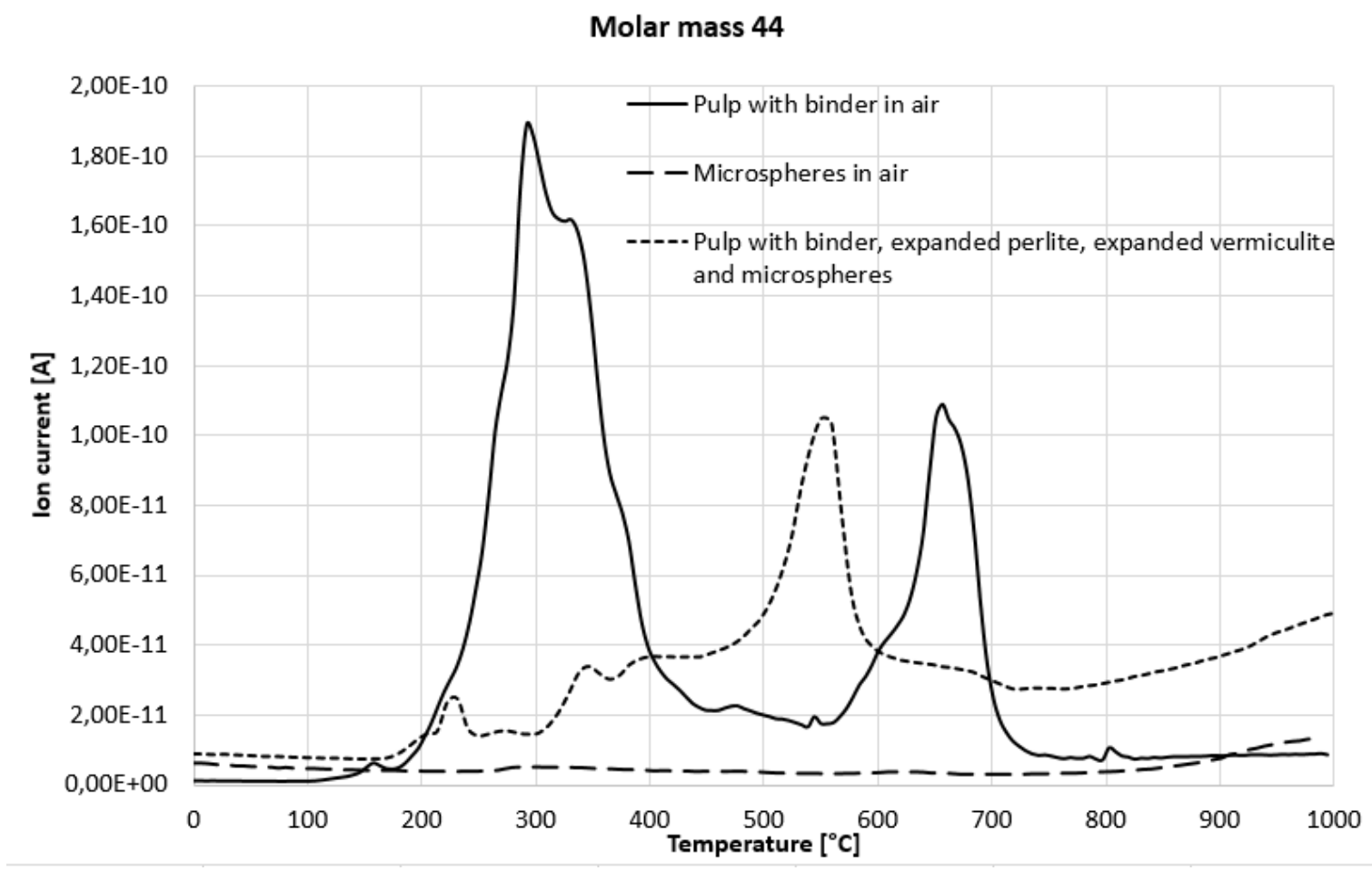

Fig. 7. Expanded perlite, expanded vermiculite and microspheres influence on mixture degradation observed at a molar mass of 44 - evolution in air

tributable to the fact that microspheres alone do not emit large amounts of carbon dioxide compared to the completed sample with all three additives. The peak of microsphere decomposition is observed at a temperature of $665^{\circ} \mathrm{C}$ which is a consequence of $\mathrm{CaCO}_{3}$ decomposition present in microspheres [11]. The Emission of $\mathrm{CO}_{2}, \mathrm{CO}$ from microspheres is a result of the process of combustion and of the physical decomposition of the material, which releases gas from pores. This has been observed in other studies [19].

\section{DISCUSSION AND CONCLUSION}

The mixtures being tested were prepared with waste paper as the main component, so degradation also involved cellulose derivatives and organic admixtures and contaminations, which might interfere with the analysis. As a result, the degradation of the mixture which mainly involves cellulose takes place in a broader spectrum of temperatures than pure cellulose test results have shown $[12,13,14,17]$. The natural emission of $\mathrm{CO}_{2}$ from natural mineral compounds at elevated temperatures, which has been observed in other studies [19], can be another factor. Thermal degradation of the mixtures under study does not produce any gaseous products other than those expected, such as $\mathrm{CO}_{2}$, $\mathrm{CO}, \mathrm{C}_{3} \mathrm{H}_{8+}, \mathrm{C}_{\mathrm{x}} \mathrm{H}_{\mathrm{y}}$, which is extremely important in designing new materials that can be thermally degraded in their applications.

It seems to be the key conclusion from these experiments that expanded perlite and expanded vermiculite, together with microspheres, absorb carbon dioxide emitted in the process of decarbonization and the degradation of cellulose and other carboniferous materials present in the samples under study in which waste paper was used as the main ingredient.

\section{REFERENCES}

1. Demirborga R., Gul R. Thermal conductivity and compressive strength of expanded perlite aggregate concrete with mineral admixtures. Energy and Buildings, 35(11), 2003, 1155-1159.

2. Haustein E., Quant B. The characteristic of selected properties of the cenospheres - Fraction of fly ash - By - Product of coal combustion-In Polish. Gospodarka Surowcami Mineralnymi, 27(3), 2011, 95-111.

3. Holtzer M., Drożyński D., Bobrowski A., Makselon J. Method of the moulding sands binding power assessment in two-layer moulds systems. Archives of foundry engineering, 13(2), 2013, 39-42. 
4. Kristkova M., Weiss Z., Filip P. Hydration properties of vermiculite in phenolic resin friction composites. Applied Clay Science, 25(3-4), 2004, 229-236.

5. Liang Y., Yu J., Feng Z., Ai P. Flammability and thermal properties of bitumen with aluminium trihydroxide and expanded vermiculite. Construction and Building Materials, 48, 2013, 1114-1119.

6. Losiewicz M., Halsey D., Dews J., Olomaiye P., Harris F. An investigation into the properties of micro-sphere insulating concrete. Construction and Building Materials, 10(8), 1996, 583-588.

7. Mazzoni A.D., Aglietti E.F. Aluminium reduction and nitriding of aluminosilicates. Thermochimica Acta, 327(1), 1999, 117-123.

8. Peletskii V.E., Shur B.A. Experimental study of the thermal conductivity of heat insulation materials based on expanded vermiculite. Novye Ogneupory, 11, 2007, 41-43.

9. Pezarski F., Izdebska-Szanda I., Smoluchowska E., Świder R., Pysz A. Zastosowanie mas formierskich ze spoiwem geopolimerowym do produkcji odlewów ze stopów Al. Prace Instytutu Odlewnictwa, 2, 2011, 23-34.

10. Pichor W., Janiec A. Thermal stability of expanded perlite modified by mullite. Ceramics International, 1, 2009, 527-530.

11. Posniak M., Koziel E., Jeżewska A. Szkodliwe substancje chemiczne w procesie przetwórstwa żywic fenolowo-formaldehydowych. Bezpieczeństwo pracy nauka i praktyka. Ministerstwo ochrony środowiska, 3, 2000, 8-11.

12. Scheirs J., Camino G., Tumiatti W. Overview of water evolution during the thermal degradation of cellulose. European Polymer Journal, 37, 2001, 933-942.

13. Shafizadeh F., Bradbury A.G.W. Thermal degradation of cellulose in air and nitrogen at low temperatures. Journal of applied polymer science, 23, 1979, 1431-1442.

14. Shen D.K, Gu S. The mechanism for thermal decomposition of cellulose and its main products. Biorescure Technology, 100, 2009, 6496-6504.

15. Suvorov S.A., Skurikhin V.V. High-Temperature heat-insulating materials based on vermiculite.
Novyer Ogneupory, 12, 2002, 24-31.

16. Suvorov S.A., Skurikhin V.V. Vermiculite - a promising material for high-temperature heat insulators. Novyer Ogneupory, 2, 2003, 44-52.

17. Tian C.M., Shi Z.H., Zhang H.Y., Xu J.Z., Shi J.R., Guo H.Z. Thermal degradation of cotton cellulose. Journal of Thermal Analysis and Calorimetry, 55, 1999, 93-98.

18. Torres M.L., Garcia-Ruiz P.A. Lighweight pozzolanic materials used in mortars: Evaluation pf their influence on density, mechanical strength and waters absorption. Cement and Concrete Composites, 31(2), 2009, 114-119.

19. Wyszomirski P., Galos K. Surowce mineralne i chemiczne przemysłu ceramicznego. AGH, Kraków 2007.

20. Yilmazer S., Ozdeniz B. The effect of moisture content on sound absorption of expanded perlite plates. Building and Environment, 40(3), 2005, 311-318.

21. Zawieja Z., Sawicki J. Expanded perlite, expanded vermiculite and microspheres as fillers in new generation paper pulp mixtures used for contact with liquid metal. Advances in Science and Technology Research Journal, 9(26), 2015, 83-88.

22. Zawieja Z., Sawicki J. Gas emissivity of a modified cellulose mix at the temperature of $900{ }^{\circ} \mathrm{C}$. Archives of Foundry Engineering, 15(3), 2015, 91-94.

23. Zawieja Z., Sawicki J. Gas evolution quantitative analysis at a temperature of $900{ }^{\circ} \mathrm{C}$ of a cellulose mixture modified by mineral additives. Archives of metallurgy and materials, 61(2B), 2016, 1051-1055.

24.Zawieja Z., Sawicki J. Polish Patent No P. 225852, 2014.

25. Zawieja Z., Sawicki J., Gumienny G. Analiza porównawcza kształtek ceramicznych z celulozowymi wykorzystywanymi do tworzenia układów wlewowych w odlewnictwie. Inżynieria Materiałowa, 5. 2014, 434-437.

26. Zawieja Z., Sawicki J., Gumienny G, SobczykGuzenda A. Investigation of an advanced cellulose profile used for the manufacture of gating systems. Archives of Foundry Engineering, 13(3), 2014, 123-128. 